\title{
ISSUES AND TRENDS IN NIGERIAN LOCAL GOVERNMENT: THE EXAMPLE OF LAGOS STATE
}

\section{I.B. Bello-Imam NISER, Ibadan.}

\section{Introduction}

The financial and human resources available to Nigerian local government councils hardly correspond to the general functions they are expected to perform. Revenue is often not available as and when due, and in the right magnitude. Under such circumstances, the service delivery function of these councils falls short of expectation. Underlying this shortfall are specific administrative and financial problems. In general, all local governments in Nigeria appear to be saddled with these problems in almost equal proportions. Academic analyses of the local government system in Nigeria have been largely limited to either of these problems, and have employed the same common strategy, of examining them in a 'global' dimension.

Beyond the assumptions of commonality of problems underlying the prevailing systems approach to the study of Nigerian local government, this paper argues that there is considerable room for differentials between and within the states. These differentials are to be seen in the actual level of resources (especially financial and human) of the council, the specific functions, they are able or can perform (given also their local needs), and their respective levels of competence.

Disparities in available financial resources derive primarily from (in fact are inbuilt) the operative revenue allocation formula and are only accentuated by other factors such as the internal revenue generation efforts of the councils. Besides, the functional prescription of the 1979 Nigerian Constitution applies to all local governments in its uniformity. This situation in which tasks, but not resources, are uniformly distributed leads to differentials in achievement depending on the status, size or population of the councils.

It is this gap in the study of Nigerian local government that this paper intends to fill. The objectives of the study, therefore, are: (i) to, identify and analyse those pertinent issues and trends in the contemporary development of the Nigerian local government system that have militated against optimal functional performance of the local governments; and (ii) to demonstrate how these issues and trends have defined different problems and functional foci for different local governments and hence eventually led to perceivable differentials in levels of competence. 
These objectives are drawn up against the background of an implicit national desire to achieve a relatively uniform level of grassroots development across ${ }^{1}$ the country. Although more than two issue characterize he contemporary Nigerian local government system, this paper lira-its detailed assessment to specific trends relating to finance and manpower.

Why is the focus on issues and trends? It is acknowledged that the local government constitutes the most critical level of government »-here the momentum to sustain national development can be created. This probably informs the contemporary pervasive optimism in the minds of political actors for the devolution of certain developmental functions to this level of government. Ideally, local governments should have sufficient financial and manpower resources to execute their proper functions. The rediscovery of this pivotal role of local governments in Nigeria, predicated on the realisation that all erstwhile central development efforts never really achieved their goals, commends reason. If the current pursuit of grassroots development is not to prove elusive, it is necessary to identify critical issues (problems) and trends to which solutions must be proftered on a long term basis. State.

The study is based on data from a survey of local government councils in Lagos

The decision to focus on Lagos State has a historical basis. The area round Lagos has about the longest history of established local government in Nigeria, dating back to the establishment, in October 1899, of a 'General Sanitary Board' with the Governor of the Southern Region as Chairman. A representative system of local government was to emerge out of this in 1971. The contemporary significance of Lagos State is that its local governments remain the most developed in contemporary Nigeria. Besides, Lagos State local government councils have high level manpower and enjoy regular payments of state allocations.

\section{Review}

The inadequacies of the multifarious systems of local government administrative practices in Nigeria prompted a nation-wide reform in 1976. This reform brought certain issues to prominence and occasioned trends which continue to have crucial impact on the performance of Nigerian local governments. For instance, the reform provided for each local government to have a population of between 150,000 and 700,000, but with no upper limit for continuous municipality which need not be split simply on the basis of its large population. This way, the possibility of variations in size, population and status of the local governments was recognized., However, as this review highlights, the most critical issues and trends which set the stage for stunted and differential performance of local councils were in the region of functions, 
finances, and administrative structures, especially, availability of man-power.

The 1976 reform was most outstanding in the recognition it accorded the local government as a distinct level of government with defined, boundaries, clearly stated functions and provisions for ensuring adequate human and financial resources while imposing a nationwide uniformity within practicable limits. This was supposed to be so regardless of the fact that it was still the province of the state government to ensure the existence of the local government councils and provide for their structure, composition, finance and functions (Akande, 1982).

The 1976 reform introduced a certain uniformity in critical elements of the local government system, not least the functions which they could perform. Generally, the relevance of local governments was enhanced by the increased in the number their functions which came to include those (i) which required detailed local knowledge for efficient performance; (ii) in the performance of which success depended on community responsiveness and participation, and (iii) which were of a personal nature requiring provisions close to where the affected individuals live and in which significant use of discretion or understanding was needed. These functions were prescribed for Nigerian local governments and constitutionally entrenched in the Fourth Schedule to the 1979 Constitution parts of which were suspended when the military seized power in December 1983.

This uniformity of functions as constitutionally provided led to a certain parochial expectation of uniformity of competence, performance and achievement on the part of local governments as they strove to contribute to Nigeria's national development from the grassroots.

With their recognition as the third tier of government, local governments now require adequate resources in the form of finances and personnel as the base to launch out in their performance of the stipulated functions.

There are five easily discernible sources of revenue open to Nigerian local governments: grants, local tax (poll tax), rates or property tax, fees and charges, and loans (Bello-Imam, 1985). These may be regrouped into external and internal sources. The key external source of revenue for Nigerian local governments has been grants in the form of financial assistance given by both federal and state governments either to help local governments undertake new functions or simply to cope with the burden of their existing functions.

Federal grants aimed at the 'stimulation of new services' at the periphery while concurrently ensuring maintenance of common or uniform standards of service delivery throughout the country. State grants related more to (i) the execution of specific projects at the local level, 
and (ii) 'matching grants' given as incentive for the performance of certain functions, for example, for efficiency in collection of local taxes fees and charges. These grants fall within the context of the 'Statutory Allocation' which federal and state governments were obliged to give local governments and which entitled the latter to definite percentages of both federally-collected revenue and internally-generated revenue of state governments.

Statutory allocations derive from a simple formula which states that 10 percent of the proceeds of the Federation Account plus 10 percent of the internally-generated revenue of the state government should accrue to the local governments. In addition local governments are $r$ laced to reap from their internal revenue sources local tax, rates, fees and charges, and from loans. Thus, by the new Guidelines, the whole yield of property rates, as well as 'development' capitation and all liquor licencing revenue accrue to local governments.

It was anticipated that from these multiple sources, Local Governments were assured of a veritable financial base to pursue their functions efficiently and effectively, and above all, uniformly to maintain even development at the grassroots.

Given a certain modicum of financial resource availability, the major responsibility for functional performance at the local level rests on the staff. Since the initial organisation of democratic local government in Eastern "Nigeria in the 1950's lack of executive capacity has been a critical problem. The caliber of staff and manner of their recruitment made the councils 'demonstrably ineffective, inefficient and corrupt'. Yet the success of local governments and their ability to deliver services depend, among other things, on a highly-motivated well trained and effective staff. This was lacking in the pre1976 local governments and the problem logically recommended itself in the 1976 reforms.

In order to ensure an effective mobilisation of the manpower at this level, local governments are required to recruit highly trained staff members.

The Local Government Service Board is supposed to be the equivalent of the Federal and State Civil Service. Commissions and was to be responsible for all employment, postings, promotion and discipline of the Local Government Staff though it could delegate internal postings and minor disciplinary matters to Establishment Committees of Local Governments subject to the right of appeal to the Boards. In order to actualize the availability of -trained manpower at the local level the Federal Government designated and funded three universities in the country as National Training Centres for local government staff.

Beyond these general trends, how have these issues relating to differential resource availability (financial and human) affected, in practical terms, the functional performance and service delivery capacity of the 
different local governments? The next section attempts to answer this question by analyzing the relevant issues and trends as they operate in Lagos State.

\section{CURRENT ISSUES AND TRENDS}

The 1976 reforms created eight Local Governments in Lagos State. Between 1979 and 1983 civilian politicking led to expansion to 23 Local Governments, a situation which was reversed only when the military returned to power. The original eight Local Governments which have remained are Badagry, Epe, Ikeja, Ikorodu, Lagos Island, Lagos Mainland, Mushin and Shomolu. The other 15 Local Governments were turned into Area Offices of these eight, to enable, as it was claimed, the rendering of grassroots services at very close range to the communities.

As the seat of the Federal Government and also Nigeria's commercial headquarters, the area of Lagos is substantially urban. This has tended to becloud the fact that the rural phenomenon is not alien to Lagos State. On the basis of the following criteria: (i) stage of physical planning (ii) availability of basic infrastructure such as roads, electricity and water supply (iii) presence of industrial and commercial environment, (iv) standard of habitat, and (v) size of population and the social, economic and cultural standard of the community, at least three Local Governments in Lagos State can be classified as rural Local Governments. These are Badagry, Epe and Ikorodu with 89.2, 95.5 and 96.5 percent rurality respectively (National Concord, 1988). In contrast are Lagos Island, Lagos Mainland and Mushin respectively with 80.0, 81.7 and 96.7 percent urbanity. Specifically Mushin Local Government, with a population of about one million people, has jurisdiction over a highly urbanised and thickly populated area.

This often insufficiently ^emphasize fact (that is, the status of the Local Government), together with other variables such as population, physical, size, etc., are critical in defining, for instance, the level of resources internally generated and relevant stock of manpower both of which related to performance differentials between Local Governments.

Financial Resources: Like in other states of the Federation Local Governments in Lagos State derive their revenue from the following sources: (i) 10 percent share of the Federation Account; (ii) 10 per. cent of internally generated revenue of the Lagos State Government; and (iii) internally-generated revenue from rates and fees, from license .and-other facilities, and revenue from commercial ventures. In addition, however, has been the implantation of the World Bank Rating Valuation consisting of valuation and general revaluation of numerous pro- 
perties throughout the state-a programme which was supposed to substantially increase the revenue accruing to local governments from tenement rates.

The prevailing revenue allocation formula in Lagos State has been based on the following indices: $40 \%$ - Population; $40 \%$-Equality; 10\% - Internally generated revenue efforts of the Councils; and $10 \%$ - Social services provided by the Councils.

Over the years this formula has led to considerable differentials between the local governments in terms of financial resource available from both federal and state sources as reflected in Table 1 . The table further reflects that financial distribution has mostly favoured the more urban local governments with dense population and which are further placed to favourably generate higher internal revenue, and under pressure for service provision for their teeming population. Thus, year by year the highest allocations have generally accrued to Mushin, Lagos Island, Lagos Mainland and Ikeja. (The exceptional windfalls to Epe '(1982 and 1984) and Badagry (1983) both of which are rural local governments, were due more to special attention than to any formula in accounting). But for Ikorodu and Shomolu, allocations for 1985 were high on the average - a fact which must be appreciated in the context of the unfolding desire to give local governments a new lease of life.

The articulation of revenue formula for disbursing of local government finance in Nigeria has been a subject of serious politicization. There has accordingly been notable variations with different regimes. This has meant a variation of what finances accrued to local governments at any point in time. The various formulae have had one thing in common: they have unwittingly sustained inequalities in the financial resources available to local governments in perpetuity, thereby adding to the lack of uniformity in service delivery and capital development capacities.

Whereas in 1978/79 the majority of local governments generated between 20 percent and 70 percent of their total revenue, by 1983 the corresponding figures had dropped to between 4 percent and 30 percent. (This was to pick, up again with the vigorous revenue drive embarked upon by the military administration under the canopy of the War Against Indiscipline (WAI).

In Lagos State the central source was internally generated revenue, with crucial dependence-on Local government rates (tenement rates). In this regard Table 2 compares favourably with Table 1. Yet the margins of differentiation in terms of resource availability continues along the trend identified above in relation to statutory allocations. Thus while Lagos Island could generate over N17 million and N16 million respectively in 1983 and 1985, Ikorodu Local Government could only generate a pittance of N635,946.26 and N1.156 million respectively for the 


\section{Annals of the Social Science Council of Nigeria}

Table 1: Lagos State: Summary of Local Government Actual Revenue (1980-1985) Federal Statutory Allocation and State Grants

\begin{tabular}{|l|l|l|l|l|l|l|l|}
\hline S/No. & Local Government & $1980^{l}$ & $1981^{l}$ & $1982^{l}$ & $1983^{l}$ & $1984^{l}$ & $1985^{l}$ \\
\hline 1 & Badagry & $973,002.22$ & $4,140,668.85$ & $7,210,498.85$ & 7,5 If, 26 2. 85 & $5,525,880.47$ & $10,726,916.00$ \\
2 & Epe & $999,767.81^{*}$ & $4,979,181.31$ & $9,305,945.98$ & $6,277,224.57$ & $6,009,257.00$ & $10,550,625.00$ \\
3 & Ikeja & $1,484,777.71$ & $6,518,118.59$ & $7,150,254.26$ & $6,979,679.46$ & $5,010,013.00$ & $10,639,923.00$ \\
4 & Ikofodu & $569,283.75^{*}$ & $3,223,335.19$ & $3,965,097.99$ & $3,960,297.32$ & $3,628,946.34$ & $5,126,676.80$ \\
5 & Lagos Island & $2,203,056.23^{*}$ & $8,855,671.01$ & $8,153,921.98$ & $12,146,030.32$ & $4,207,144.00$ & $6,316,346.00$ \\
6 & Lagos Mainland & $1,783,634.80^{*}$ & $6,222,478.44$ & $5,439,827.35$ & $5,373,414.28$ & $4,702,989.80$ & $10,278,469.00$ \\
7 & Mushin & $1,443,972.70$ & $7,512,544.36$ & $11,391,233.18$ & $9,863,411.71$ & $8,110,557.00^{*}$ & $* 14,5$ \\
8 & Somolu & $826,708.99$ & $3,518,555.15$ & $5,304,369.03$ & $5,668,006.08$ & $3,298,209.00$ & $16,781.00^{* \prime}$ \\
8 & S & & & & & & \\
\hline
\end{tabular}

Sources: 1. Returns from the Local Government and Records in the Ministry

2. Lagos State: Local Government Report 1984-85 for all Eight Local Governments Respectively * State Statutory Grant figures not available/included 
Issues and Trends in Nigerian Local Government:... 75

Table 2: Lagos State: Summary of Local Government's Internally Generated Revenue 1980-1985

\begin{tabular}{|l|l|l|l|l|l|l|l|}
\hline S/No. & Local Government & $1980^{l}$ & $1981^{l}$ & $7982^{\prime}$ & $1983^{l}$ & $1984^{2}$ & $1985^{2}$ \\
\hline 1 & Badagry & $3,496,412.43$ & $2,486,941.60$ & $2,260,821.92$ & $2,172,41.32$ & $3,163,375.11$ & $3,878,967.44$ \\
2 & Epe & $72,569.21$ & $26 ?, 014.33$ & $359,390.41$ & $469,127.56$ & $559,834.00$ & $1,057,253.00$ \\
3 & Ikeja & $1,496,758.31$ & $3,735,351.70$ & $4,620,309.49$ & $3,988,658.52$ & $5,284,382.00$ & $7,734,666.00$ \\
4. & Ikorodu & $541,299.02$ & $518,291.78$ & $555,663.37$ & $635,946.26$ & $990,111.30$ & $1,156,657.00$ \\
5. & Lagos Island & $3,867,954.53$ & $13,146,150.86$ & $15,183,537.21$ & $17,440,634.04$ & $13,560,022.00$ & $16,315,709.00$ \\
6. & Lagos Mainland & $3,218,847.25$ & $4,567,520.65$ & $5,922,919.65$ & $5,612,599.34$ & $7,487,645.25$ & $9,657,334.00$ \\
7. & Mushin & $2,580,0 £ 0.90$ & $3,459,478.43$ & $3,341,850.73$ & $4,812,594.02$ & $5,299,367.00$ & $9,168,125.00$ \\
8. & Somolu & $833,727.23$ & $1,716,488.26$ & $1,834,162.29$ & $1.908,897.92$ & $2,950,423.00$ & $4,755,491.00$ \\
\hline
\end{tabular}

Sources: 1. Returns from the Local Government

2. Lagos State: Local Government Report 1984-85 for all the Eight Local Governments Respectively. 


\section{Annals of the Social Science Council of Nigeria}

same years for the performance of the same, if not more (given its rural status in an-urban setting), sets of functions. This further objectifies the conditions for differential achievement.

The general buoyancy of the 'urban' local governments was such that by December 1987, the Mushin Local Government had enough money in its Fixed Deposit Account to yield an average of $\$^{\wedge} 80,000$ monthly (Interview I).

It was probably in anticipation of such mammoth differentials that the Federal Government suggested (post-19 76 reforms) that charges be harmonised not only between various local governments within a State, but also between neighbouring states. The establishment of a Local Government Revenue Board in Lagos State in 1980 was also in response to an "ascertaining and glaring ineffective and inefficient" collection of local government revenue by some of the existing councils. Unfortunately these measures only accentuated the disparities.

\section{Human Resources:}

Beyond the apparent assurance of "adequate" financial resources, the state of human resources actually on the ground for the execution of local government functions shows a gross imbalance in human resource development and utilization, and an acute variation across local governments and even within departments of local governments. This variation which is both general and specific questions the basis for uniformity of approach to prescribe tasks even in a situation (non-existent though)

Table 3 shows the picture for local governments in Lagos State. While generally the local governments lack the much desired executive capacity to translate policy measures into reality, the shortage varies, just as the ability to attain the necessary translation. This relates to the problem of a certain improper use of even the available Staff. Table 3 reveals a large concentration of personnel in the Health Departments but with the distribution highly in favour of the large, urban and economically 'advantaged" local governments. There is an especially critical shortage of trained accounting staff to maintain proper records in the Treasury Departments, while Agriculture and Social Services Departments are seriously understaffed with a combined workforce of 49 employees or less than one per cent of the total staff strength of local governments in Lagos (Okoosi, 1988). These, of course, were represented only in the rural local governments. Further insight (not reflected in Table 3) shows the predominance of the pattern of critical manpower shortage on top with over-establishment at the bottom of the hierarchy. The shortage has been due, among other things, to the inability of Local Governments to recruit competent hands as a result of the prevailing embargo employment. 
Issues and Trends in Nigerian Local Government:... 75

Table 3: Lagos State: Number of Staff in Local Governments

\begin{tabular}{|c|c|c|c|c|c|c|c|c|}
\hline \multirow[t]{2}{*}{ Local Govt. } & \multicolumn{8}{|c|}{ Departments } \\
\hline & Admin & $\begin{array}{l}\text { Treasury } \\
\text { Finance }\end{array}$ & $\begin{array}{c}\text { \& Eng. \& } \\
\text { Works }\end{array}$ & Health & $\begin{array}{l}\text { Social } \\
\text { Services }\end{array}$ & Agric. & Total & $\%$ \\
\hline Badagry & 278 & 98 & 182 & 528 & 15 & & 1101 & 14.5 \\
\hline Epe & 124 & 53 & 32 & 221 & 6 & & 436 & 5.7 \\
\hline Ikeja & 307 & 85 & 274 & 610 & - & - & 1276 & 16.8 \\
\hline Ikorodu & 114 & 63 & 119 & 212 & - & - & 508 & 6.7 \\
\hline Lagos Island & 481 & 17 & 228 & 621 & 5 & $17(\mathrm{Ed})^{*}$ & 1369 & 18.1 \\
\hline Lagos Mainland & 337 & 10 & 442 & 548 & 4 & & 1341 & 17.7 \\
\hline Mushin & 178 & 177 & 149 & 592 & _ & _- & 1096 & 14.5 \\
\hline Somolu & 321 & 4 & 8 & 90 & $\overline{2}$ & & 425 & 5.6 \\
\hline TOTAL & 2140 & 507 & 1534 & 3422 & 26 & 23 & 7552 & \\
\hline$\%$ & 28.3 & 6.7 & 19.0 & 45.3 & 0.3 & 0.3 & & 100 \\
\hline
\end{tabular}

Source: Nigerian Institute of Social and Economic Research (NISER) Comprehensive Staff Audit of Local Governments in Lagos State 1987.

*Education Department. 
Functional Specificities and Achievement Capacity The functions of local governments in Nigeria have remained those indicated in the Fourth Schedule to the 1979 Constitution. However, in practice, a good number of the stipulated functions could not be performed, and where performed at all, marginally and half-heartedly in some local governments. The reasons as identified above have come to include: (a) inadequate financial capacity, (b) lack of technical manpower; and (c) erosion of these functions particularly in the revenue-yielding areas, by the state governments, thereby reducing the revenue base of local governments.

It is, however, not the intention of the framers of the constitution to put local government councils in a position where they would be subjected to the cavalier- and whimsical tinkering of state governments. What actually cemerged, on the contrary, was a situation where states still had to make the laws which not only established local governments, but also conferred on them the functions which they would perform, though such functions were to include those specified in the constitution (Akande, 1982).

Given the prevalent mixed grill of problems discussed so far, local governments have had to determine for themselves basic priority functions. This determination has been predicated on resource availability, population, sometimes land area, but critically, the status (urban or rural) of the Local Government. The case of Mushin in Lagos State is instructive.

Mushin Local Government is highly urbanised and thickly populated. Until recently, it remained largely unplanned with little or no social amenities. By February 1984 the council had the reputation of presiding over the dirtiest local government. But it had the capacity to generate much revenue internally. Logically, its functional imperative became focussed on environmental sanitation. Table 4 reflects the tremendous energy channelled into this exercise.

Other major priorities of this local government have to do with revenue collection, provision of health (and social) services, and capital 'projects - mainly the provision of infrastructural facilities as follows: (i) construction of drains, culverts, (ii) construction/surf acing of roads (iii) provision of street lights; (iv) provision of water taps;(v) provision of public (including VIP) toilets; (vi) provision of market stalls; and (vii) beautification of roundabouts and open spaces. Largely, these functional foci have been dictated by its urban status, and facilitated by its relative financial (and manpower) buoyancy. It was in like manner that Lagos Island in 1985 gradually shifted its emphasis from what it called "reassurance" to "service delivery and result orientation".

In addition to performing these functions (given once again the generally 'urban' level of Lagos), the rural local governments on the 
other hand emphasise functions relating to community development, chieftaincy matters, and crucially, agricultural programmes. Notably, a Divisional Chieftaincy Committee was inaugurated in Epe in 1984 to deliberate on chieftaincy matters and other interests that affect life in the communities. In Ikorodu, maize, cassava and vegetable were directly cultivated by the local government. The essence according to the local government is:

"By our effort (to give) a lead to the people of this division to take to fanning for the purpose of planting food crops so that we could have nough for our people"

(Ikorodu LG Report 1984-85:11).

The critical fact is that this functional direction was dictated by the rural status of the local government.

The ultimate becomes that considerable differentials between local governments as a result of variables (independent and intervening) lead logically to different functional imperatives and achievement capacity. A basis for uniformity hardly exists. Therefore, whereas it is officially acknowledged that the issues considered in the determination of the level of performance of the prescribed (uniform) functions are (i) the complexity of the service of function; (ii) the ability of the local government to carry it through; and (iii) the financial resource available to the local government for its performance, in practice different criteria have emerged as evident in the various competitions engaged in since 1985. In the 'local government of the Year Award' (Lagos State,

\section{Table 4: Mushin LG: Environmental Sanitation}

\begin{tabular}{|c|c|c|c|}
\hline$S / N$ & & 1984 & 1985 \\
\hline 1. & No. of premises inspected & 23,928 & 30,969 \\
\hline 2. & No. found satisfactory & 17,647 & 23,327 \\
\hline 3. & No not satisfactory & 6,281 & 7,642 \\
\hline 4. & No. of abatement notices served & 4,975 & 5,413 \\
\hline 5. * & No. complied with & 3,249 & 3,023 \\
\hline 6. & No. not complied with & 11,726 & 2,390 \\
\hline 7. & $\begin{array}{l}\text { No, of persons prosecuted for violating } \\
\text { the environmental Sanitation Edict }\end{array}$ & 3,019 & 2,388 \\
\hline 8. & No. of illegal street traders prosecuted & 631 & 2,402 \\
\hline 9. & No. of persons convicted & 498 & 3,770 \\
\hline 10. & $\begin{array}{l}\text { Total amount realized as Court fines in } \\
\text { respect of Environmental Sanitation } \\
\text { (including fines imposed on street tra }\end{array}$ & . & \\
\hline
\end{tabular}

Source: Lagos State, Mushin Local Government Report 1984-85, 5. 
1985) the yardsticks were internal revenue effort, degree and control of fraud and other revenue loss, degree of cleanliness of the local Government Area, and volume and quality of capital projects. It is instructive that in the Lagos case three winners emerged with Ikeja a as local government of the Year, while Lagos Mainland won the Urban trophy, and Epe, the Sub-Urban trophy-a no minute indicator of the objectively (and subjectively) informed differential capabilities of Nigerian Local Governments'.

\section{Conclusion}

To be effective catalysts of grassroots mobilisation and development, local governments must be service - oriented with appropriate financial and manpower resources. The failure to achieve some level of 'uniformity' in the development and functioning of Nigeria local-governments have been a reflection of deep-rooted variations and disparities in their resource endowments, statutorily Or practically orchestrated, de facto functional variation regardless of the unequivocability of the 1979 Constitution in its functional assignments.

Informing this trend are peculiarities (status, size, population ect) of the various local governments which mean that they are differently advantaged/disadvantaged with respect to given functions, and resource generation and regeneration.

A most critical issue impinging on the performance of Nigerian local governments has been finance. It is encouraging that the Nigerian government is not only proposing to increase the bouyancy of the local government fund but also to adopt mechanisms of channelling such funds directly to local governments. What remains, therefore, is for the government of the day to ensure that human resources at the local level match both the finances, functions and responsibilities of local governments. It is only with an 'optimal balance' between these three critical variables that Nigerian local governments will cease to be structural decorations at the periphery of government administration. One way of approaching the issue might be, through articulation and implementation (via the local government system) of a complementary political development dimension to the vigorously pursued rural development programme all over die country. 
Issues and Trends in Nigerian Local Government:... 81

\section{References}

Adamolekun, L. (1983). Public Administration: A Nigerian and Comparative Pers pective, Lagos: Longman Nigeria Ltd.

Akande, J.O. (1982), Introduction to the Nigerian Constitution. London: Sweet and Maxwell.

Bello-Imam, I.B. (1985), "Financing Municipal Governments: The Case of Nigerian

Local Government Councils" NAGARLOCK, Vol. XVII, No. 3 July-September, 1985, pp. 77-96.

- (1986) "Labour Utilisation at the Local Government Level" Development Outlook

(Nigeria), Vol. 1,No. 5,October 1986,pp.4-9.

Dudley, B. (1982). An introduction to Nigerian Government and Politics, London: Macmillan.

Federal Republic of Nigeria (1976), Guidelines For Local Government Reform. Kaduna: Government Printer.

-----(1979) Constitution of the Federal Republic of Nigeria 1979

- (1981) Revenue Allocation Act of 1981

----------(1984) "Local Government "Report by the Committee on Review of

Local Government Administration in Nigeria.

Lagos State Government, Lagos State Progress Report 1984-85 Local Government and Chieftaincy Affairs.

- Lagos State Local Government Report 1984-85, (for all the respective Local Governments in the State).

National Concord (Nigeria) February 1, 1988 p.l "Supplement on Lagos State".

Okoosi, TA. (1988) "Manpower Structure and Training Requirements for Local

Governments: The Case of Lagos State", Paper presented at NISER Seminar Series, February 10.

Permanent Secretary, Ministry of Local Government, Rural Development and

Chieftaincy Affairs, Brief on The Local Government Administration in Lagos State, at the Briefing Session Held for the Visiting External Affairs Officers from the Foreign Service Academy of Nigeria in the Former House of Assembly Complex, Ikeja on Thursday 2nd October, 1986 at 1035 a.m. 